Andrew Young School of Policy Studies Research Paper Series

Working Paper 06-55

May 2006

Department of Economics

International Studies Program

\title{
Credit Expansions and Financial Crises: The Roles of Household and Firm Credit
}

\author{
Berrak Buyukkarabacak \\ Emory University
}

\section{Neven Valev} Georgia State University

This paper can be downloaded at:

http://aysps.gsu.edu/publications/2006/index.htm

The Social Science Research Network Electronic Paper Collection: http://ssrn.com/abstract $=903980$ 


\title{
Credit Expansions and Financial Crises: The Roles of Household and Firm Credit ${ }^{*}$
}

\author{
Berrak Buyukkarabacak $^{\mathrm{a}}$ and Neven Valev ${ }^{\mathrm{b}}$
}

17 May 2006

JEL Classification: E44, F41, G21

Keywords: Financial Crisis; Household and Firm Credit Growth

* We would like to thank Emory University Macro Lunch Group participants, especially Robert Chirinko, Stefan Krause, Richard Luger, and Jerry Thursby for helpful comments and suggestions.

${ }^{a}$ Corresponding Author: Department of Economics, Emory University, 1602 Fishburne Drive, Atlanta, GA 30322-2240, e-mail: bbuyukk@emory.edu, phone: 404-727-1022

${ }^{\mathrm{b}}$ Department of Economics, Andrew Young School of Policy Studies, Georgia State University, Atlanta, GA 30302-3992, e-mail: nvalev@gsu.edu, phone: 404-651-0418. 


\title{
Credit Expansions and Financial Crises: The Roles of Household and Firm Credit
}

\author{
Berrak Buyukkarabacak \\ Department of Economics \\ Emory University \\ Neven T. Valev \\ Andrew Young School of Policy Studies \\ Georgia State University
}

\begin{abstract}
The literature has identified credit expansions to the private sector as an important predictor of financial crises in developing countries. We extend the literature by decomposing credit into credit extended to households and credit extended to firms. We compile a unique disaggregated data set and find evidence that household credit growth and firm credit growth have positive, distinct, and statistically significant effects on the likelihood of banking and currency crises. Furthermore, household credit growth is a particularly important predictor of banking crises in countries with a high propensity to consume.
\end{abstract}




\section{Introduction}

Rapid growth in bank credit to the private sector is a common factor associated with financial crises in developing countries. While an expansion of credit can be beneficial for economic development in the long-run, ${ }^{1}$ it may lead to macroeconomic disbalances and poor credit allocation in the short and medium term. There is abundant empirical evidence that credit expansions are often followed by banking crises and currency crises (Demirguc-Kunt and Detragiache 1997; Kaminsky, Lizondo and Reinhart 1998; Kaminsky and Reinhart 1999). ${ }^{2}$

We build on these studies by investigating how the components of private credit affect the likelihood of financial crises. In particular, we differentiate between household credit and firm credit. The literature has used the growth of total credit to the private sector, household and firm credit combined, as a predictor of crises but not separately. Yet, expansions of the two types of credit present distinct concerns for policymakers. Hilbers et. al (2005) point out that distinguishing between household and firm credit is a "key element" in evaluating the risks associated with credit expansions. To break down total private credit into household and firm credit, we use data from the national central banks of thirteen emerging economies. We find evidence that firm credit growth and household credit growth each increases the probability of a currency and a banking crisis.

\footnotetext{
${ }^{1}$ King and Levine (1993a, b), Levine (1997), and Levine et al. (2000) among others provide evidence for a statistically significant and economically important effect of financial system development on economic growth.

${ }^{2}$ For example, the IMF (2004) estimates that about three-fourths of the periods of rapid credit growth in emerging markets are associated with a subsequent banking crisis and almost seven-eights are associated with a currency crisis.
} 
Furthermore, household credit expansions combined with a low national propensity to save are an even stronger predictor of banking crises.

The paper is organized as follows. Section 2 discusses the theoretical differences and similarities between household credit and firm credit as pertaining to financial crises. Section 3 describes the data and the crisis definitions. Sections 4 and 5 present the empirical model and the estimation results, respectively. Section 6 concludes.

\section{Credit Expansions and Financial Crises: Theoretical Background and Review of the Empirical Evidence}

Credit expansions can lead to financial crises through three channels: 1) by creating external macroeconomic disbalances; 2) by inflating asset bubbles; and 3) by leading to inefficient use of resources. ${ }^{3}$ Starting with the first channel, rapid credit growth can lead to a current account deficit if the demand for goods fueled by it cannot be satisfied by domestic supply. Generally, household credit growth raises the demand for consumption goods whereas firm credit growth raises the demand for investment goods. The difference is important because borrowing to finance consumption does not add to the long-term productive capacity of an economy and to greater export earnings (Frankel and Rose 1996). Therefore, a boom in the demand for consumption goods could be particularly problematic. There is ample evidence that an increase in household credit leads to an increase in consumption (Ludvigson 1999; Bacchetta and Gerlach 1997), reduced savings (Japelli and Pagano 1994) and current account deficits (Muellbauer and

\footnotetext{
${ }^{3}$ See Kaminsky and Schmuckler (2003) for a comprehensive chronology of financial liberalizations. Credit expansions might be the result of financial liberalization policies that reduce reserve requirements, increase competition in the banking system, and liberalize international capital flows. They might also arise from an imperfectly credible exchange-rate based stabilization (Calvo 1986) or from implicit and explicit bailout guarantees (Corsetti et al. 1999a; Schneider and Tornell 2004).
} 
Murphy 1990; Miles 1992). In the context of emerging economies, expectations of future instability can also lead to a consumption boom and current account deficits as consumption is shifted from the future to the present (Calvo 1986). This process can be facilitated by the availability of credit.

The consumption boom that results from rapid credit growth can be particularly strong in countries with traditionally low savings rates. In these economies, the relaxation of credit constraints raises household indebtedness without boosting significantly future income, thus increasing default risks (see Antzoulatos 1996 and Copelman 1996 for analyses of this phenomenon in Latin America). Another consequence of a low national savings rate is that the credit booms are financed by international capital inflows, which also raises the potential for financial crises (McKinnon and Pill 1997). Conversely, firm credit growth lowers the cost of external finance to firms in countries with low saving rates and scarce capital. Rajan and Zingales (1998) show that a higher level of financial development helps financially dependent firms grow faster thus leading to higher investment and growth. The empirical specifications discussed in the following sections include an interaction term of household credit growth and firm credit growth with savings rates to test whether savings rates influence the effect of credit growth on crises as these studies suggest.

Turning to the asset price bubbles channel for crises, Bernanke et al. (1999) focus on the role of credit market frictions in business fluctuations. In their "financial accelerator" framework, endogenous developments in credit markets work to amplify and propagate shocks to the economy. During a boom, credit expands and asset prices increase, which in turn increases borrowers' net worth and leads to new lending and even 
higher asset prices. During a bust, the borrowers are not able to repay their loans and defaults increase. Allen and Gale (2000) also explore the role of credit expansions in creating asset bubbles using an asset pricing model. Their model explains the existence of bubbles by the inability of lenders to observe the riskiness of borrowers' investment projects. Borio and Lowe (2002) show that sustained rapid credit growth combined with growth in asset prices increases the probability of a financial crisis.

It is not clear whether household credit growth or firm credit growth fuel the financial accelerator process more strongly. However, the channels are likely to be different. A large portion of household credit is mortgage credit; therefore its rapid growth might result in inflated residential real estate prices, especially if households have limited access to alternative investment options such as a well developed domestic stock market (Bank for International Settlements 2005). McKinnon and Pill $(1997,1998)$, for example, discuss that the rapid growth in certain types of household lending, particularly real estate finance and consumer credit, have been more problematic than others. Conversely, growth in firm credit might be associated with growth in commercial real estate prices and/or equity prices, both of which have been associated with crises (Borio and Lowe 2002).

The third channel for crises (the inefficient use of resources) refers to the difficulties faced by overburdened loan officers to price loans appropriately when the volume of new loans created is increasing rapidly. "Evergreening" might also be prevalent, i.e. new loans are used to service old loans. Furthermore, the temporary economic boom spurred by credit-driven consumption and investment growth might be misperceived as a long-term shift in the economic potential of the economy (Duenwald et 
al. 2005). Overoptimistic expectations of future income might lead to greater indebtedness and defaults.

These problems could arise from both household and firm credit growth. However, the literature has discussed the issue primarily in terms of firm credit. For example, Corsetti et al. (1999a, b), Krugman (1998), and Scheider and Tornell (2004) argue that implicit and explicit bailout guarantees contributed to overinvestment, excessive borrowing, and current account deficits in Southeast Asia by inducing private borrowers and lenders to develop and carry out risky projects. This system, characterized by moral hazard, lack of transparency, and inefficient monitoring of projects, unraveled into a financial crisis when the low profitability of past investments and the shaky foundations of investment strategies became apparent. It is possible that the literature has focused mostly on firm credit because much of the household credit involves collateral (real estate) and therefore requires less precise judgments on the part of loan officers. Poor judgment might be less costly unless there is a large drop in real estate prices, a sharp increase in unemployment or a sharp increase in interest rates (while long-term credit rates are already fixed). However, the increase in the unsecured household debt, e.g. through increased availability of credit cards, should also be a concern since higher levels of debt to income increase the probability of defaults.

In summary, the literature has advanced a number of arguments that distinguish (with more or less clarity) between the effects of rapid growth in household credit and in corporate credit. Also, the literature has investigated empirically the combined effect of these two types of credit on both currency and banking crises. In the following sections 
we perform empirical tests of the effect of credit expansions on crises differentiating between household and firm credit.

\section{Data Description}

\subsection{Household and firm credit}

The available data sources used by the profession provide the aggregate value of credit to the private sector but do not distinguish between its household and firm credit components. Therefore, we use data from the national central bank reports of emerging market economies where historical disaggregated credit data are available. Our dataset includes the following 13 countries: Argentina, Brazil, India, Indonesia, Malaysia, Mexico, Pakistan, South Africa, South Korea, Russia, Thailand, Turkey and Uruguay. ${ }^{4}$ Although we use national sources, the definitions for the household and firm credit are consistent across countries. Specifically, household credit includes housing and consumer credit from deposit banks to households. ${ }^{5}$ The firm credit variable includes credit to nonfinancial corporations from deposit banks. Table 1 shows the labels and the time periods for household and firm credit and Table 2 shows the levels of household and firm credit as percent of GDP for each country in the sample.

We measure the growth in household and firm credit as the two years moving average of the rate of change in the household and firm credit to GDP ratios. For example, the reported 0.55 growth in household credit for Argentina in Table 3 means that household credit as percent of GDP has been expanding by 0.55 percentage points on average during the sample years. Taking an average of 2 or 3 years is customary in the

\footnotetext{
${ }^{4}$ Not all countries report data on the two types of credit. Furthermore, we excluded Nigeria since the data had several intervals of missing observations.

${ }^{5}$ In most countries these two components of household credit are not given separately.
} 
literature (Demirguc-Kunt and Detragiache 1997; Rodrik and Velasco 1999). We obtained similar results using a one year growth rate.

Table 3 shows that while the average growth in the household credit to GDP ratio was positive (0.25), the growth in the firm credit to GDP ratio was essentially zero. Hence, household credit is increasing in size relative to firm credit. Note also that while the correlation of the growth in household credit and the growth in firm credit is positive, it is not large (only 0.33 ). Hence, household credit expansions do not necessarily occur alongside firm credit expansions.

\subsection{Defining Banking Crisis}

In constructing our banking crisis variable, we used primarily two studies, Demirguc-Kunt and Detragiache (1997) and Caprio and Klingebiel (2003). DemirgucKunt and Detragiache (1997) identify an episode of distress as a full-fledged crisis if at least one of the following conditions apply: the ratio of nonperforming assets to total assets in the banking system exceeds $10 \%$; the cost to rescue operations is at least $2 \%$ of GDP; banking sector problems resulted in a large scale nationalization of banks, or generalized deposit guarantees were enacted by the government in response to the crisis.

However, Demirguc-Kunt and Detragiache (1997) do not consider the countries and the periods in which we are particularly interested. By using their definitions, we constructed our banking crisis variable using the information available via Caprio and Klingebiel (2003). A banking crisis is deemed to have occurred for a given year if the situation in the banking system satisfies one of the criteria that are mentioned above. To avoid capturing the same banking crisis period, we treat any financial distress period in 
the following year as part of the same banking crisis. Using this methodology, we identify 11 banking crises.

\subsection{Defining Currency Crisis}

In general, a currency crisis is characterized by various events, such as a sharp depreciation of the exchange rate, a reduction in foreign exchange reserves or an increase in interest rates. In this paper, we define a currency crisis in two ways ${ }^{6}:$ (1) a weighted average of the depreciation of the exchange rate and reserve losses and (2) the depreciation of the nominal exchange rate. To measure the exchange rate, we use the percentage change in the exchange rate of the national currency per US\$. For the first definition, the weights are chosen so that the two components of the index have the same conditional variance ${ }^{7}$. The weighted average of the two components exceeding its sample mean by two standard deviations or more is classified as a currency crisis.

For the second definition, a currency crisis is defined as a nominal depreciation of at least $25 \%$. This cut-off point is arbitrary; however it is consistent with the literature (Frankel and Rose 1996). To ensure that we do not consider each of the consecutive years that satisfies our criteria, we require that the change in the exchange rate not only exceeds $25 \%$, but exceeds the previous year's change in the exchange rate by a margin of at least $10 \%$. For each country-year in our sample, we define a currency crisis for a given year if the currency for any month of that year satisfies one of our currency crisis definitions. To reduce the chances of coding the continuation of the same currency crisis episode, we treat any similar threshold point reached in the following year as a part of the same currency crisis. With this methodology, we identify 12 crises using our first definition

\footnotetext{
${ }^{6}$ We are using the same definitions as Hong and Tornell (2005), which are widely used in the currency crises literature.

${ }^{7}$ The weights are chosen in the same way as Kaminsky, Lizonda and Reinhart (1998).
} 
and 13 crises by the second definition. A list of the banking and currency crisis episodes is presented in Tables 4 and 5, respectively.

\section{Empirical Model}

We begin our analysis by estimating the effects of household and firm credit growth, along with several control variables commonly used in the literature (DemirgucKunt and Detragiache 1997), on the probability of banking crises. In particular, we estimate the following equation:

$$
\begin{aligned}
& \text { Banking Crisis }{ }_{i t}=\alpha+\beta_{1} * \text { HH Credit Growth }{ }_{i t}+\beta_{2} * \text { Firm Credit Growth }{ }_{\text {it }}+ \\
& +\beta_{3} * \text { Bank Reserves/Bank Assets }{ }_{i t}+\beta_{4} * \text { M2/International Reserves } \\
& \text { it }
\end{aligned}
$$

where $\mathrm{i}$ denotes country $\mathrm{i}$ and $\mathrm{t}$ denotes the time periods. We expect the $\mathrm{M} 2$ to international reserves ratio to affect the probability of a banking crisis positively whereas the bank reserves to bank assets ratio to affect the probability of a crisis negatively. Similarly, we expect to find a negative effect of real GDP growth on banking crises as greater GDP growth reflects positive macroeconomic developments in a country. We expect that household and firm credit growth increase the likelihood of a banking crisis.

Our estimation equation for currency crises includes household and firm credit growth and control variables selected on the basis of economic theory as well as recent findings of the empirical literature (Kaminsky and Reinhart 1999):

Currency Crisis $_{\text {it }}=\mu+\gamma_{1} *$ HH Credit Growth ${ }_{\text {it }}+\gamma_{2} *$ Firm Credit Growth ${ }_{\text {it }}+$

$$
+\gamma_{3}{ }^{*} \text { Debt } / \mathrm{GDP}_{\mathrm{it}}+\gamma_{4}{ }^{*} \text { Current Account Balance }{ }_{\mathrm{it}}+
$$


$+\gamma_{5}{ }^{*}$ GDP Growth ${ }_{\text {it }}+\gamma_{5} *$ M2/International Reserves ${ }_{i t}+v_{i}+e_{i t}$

We expect to find a negative effect of GDP growth and the current account balance to GDP ratios on the probability of currency crises. The debt to GDP ratio, the M2 to international reserves ratio, and credit growth are expected to have positive effects. $^{8}$

We estimate equations (1) and (2) with two additional specifications of credit growth. First, we estimate the equations using the growth of household and firm credit growth combined. This provides a benchmark estimate similar to the estimations performed in the literature. Then we decompose credit into household credit and firm credit. Second, we interact the household and firm credit growth variables with a measure of savings rates to investigate whether the effect of credit growth is different in countries with a low/high savings rate. We create a dummy variable for countries with a high savings rate, which equals 1 if the average savings to GDP ratio during the 1976 to 2004 period is above the mean of our sample and zero otherwise. ${ }^{9}$ Table 6 shows that in our sample, the countries that have traditionally low savings rates are mainly Latin American countries, India, Pakistan, Turkey, and South Africa.

Our dependent variables are binary $(0=$ no crisis and $1=$ crisis $)$ and therefore we use a binary choice model. We estimate equations (1) and (2) using a logit model with country-specific random effects as well as a logit model utilizing population-averages.

\footnotetext{
${ }^{8}$ Because of our limited sample size, we try to be as parsimonious as possible. In addition to the variables in equation (2), we also used the short-term debt to total debt ratio and a measure of real exchange rate appreciation as independent variables. These two variables were not statistically significant and their inclusion did not affect substantially the remaining coefficient estimates. In addition to the variables in equation (1), we also introduce the real interest rate and GDP per capita, which did not have a statistically significant effect on banking crises.

${ }_{9}^{9}$ We use the historical savings rates to group our data in order to avoid a potential endogeneity problem, i.e. causality running from credit availability to saving rates.
} 
One advantage of using the population-averaged method is that it allows us to use the Huber/White/sandwich estimator of variance that produces valid standard errors. Robust standard errors are calculated by the generalized estimating equations (GEE) approach. ${ }^{10}$

\section{Empirical Results}

\subsection{Credit Expansions and Banking Crises}

Table 7 presents the results for banking crises. For our baseline specification estimated with the household and firm credit growth combined, the results show that total credit growth is statistically significant at the $1 \%$ level and has the expected positive sign. This result is in line with the literature that shows a positive effect of private credit growth on the likelihood of a banking crisis. Regarding our control variables, GDP growth is significant at the $1 \%$ level with the expected negative sign. Conversely, the M2 to international reserves ratio and the bank reserves to total assets ratios do not have a statistically significant effect on the likelihood of banking crises in our sample. ${ }^{11}$

Now, we turn our attention to the variables of primary interest: household and firm credit growth. Once we decompose the private credit growth into firm and household credit growth, we find a positive and statistically significant effect of both variables using both estimation methods. Thus, household and firm credit growth have a

\footnotetext{
${ }^{10}$ The relationship between the population-averaged robust estimator and the random effects estimator can be shown as the following (see Zeger et al. 1988 and Wooldridge, J. 2002): $\beta_{P A} \equiv \beta_{R E} /\left(1+\sigma_{c}^{2}\right)^{1 / 2}$ where $\beta_{P A}$ is the population averaged parameter, $\beta_{R E}$ is the random effects parameter and $\sigma_{c}^{2}$ is the variance of the unobserved effect $c_{i}$ conditional on $x_{i}$.

${ }^{11}$ For each of our specifications, we ran Hausman tests and could not reject the null hypothesis that random effects estimators are consistent and efficient. Nonetheless, we also estimate the models with countryspecific fixed effects. However, our data includes countries that did not experience crises during the time period we are analyzing. Using fixed effects eliminates those countries and reduces our sample size significantly. Our results for fixed effects are in line with our random effects estimation but with higher standard errors. The tables for fixed effects are available upon request.
} 
distinct influence on the likelihood of a banking crisis. Furthermore, the growth in household credit has a particularly strong predictive effect on banking crises in countries with low savings rates, as indicated by the negative and statistically significant coefficient on the interaction term of household credit growth and the dummy variable for high savings rates. Firm credit growth, on the other hand, appears to be more of a problem in the high savings countries. In our sample these are mostly the Southeast Asian countries where the crises were largely driven by booming investments funded by domestic and international capital.

In terms of marginal effects, the results imply that an increase of household credit growth from $1 \%$ to $2 \%$ of GDP results in a $2 \%$ increase in the probability of having a banking crisis. ${ }^{12}$ Once we account for the countries that have traditionally low savings rates (recall that these are mostly countries in Latin America as well as India, Pakistan, Turkey, and South Africa) the effect becomes stronger. An increase of household credit growth from $1 \%$ to $2 \%$ of GDP leads to a $20 \%$ increase in the probability of having a banking crisis in those countries. Note that such an increase in household credit growth is not uncommon. For example, in Turkey the household credit to GDP ratio increased from $0.21 \%$ to $2.36 \%$ just before the crisis in 1994 . For firm credit growth, an increase of firm credit growth from $1 \%$ to $2 \%$ of GDP results in a $1 \%$ increase in the probability of having a banking crisis. For the countries that have high savings rates, namely Southeast Asian countries, we calculate the effect of an increase from $1 \%$ to $2 \%$ in firm credit growth to be associated with an increase in the probability of having a banking crisis by $20 \%$.

\footnotetext{
${ }^{12}$ The tables with marginal effects are available upon request.
} 


\subsection{Credit Expansions and Currency Crises}

Next we report our estimations of the currency crises models. Table 8 reports the estimates using the first definition of currency crises which incorporates information on currency depreciation as well as foreign exchange reserves. The dependent variable in Table 9 is based on currency depreciation only. Overall the results using the two definitions are similar. All of the control variables have the expected signs and are statistically significant. GDP growth and the current account balance have a negative and statistically significant effect on the probability of having a currency crisis. The debt to GDP ratio and the M2 to international reserves ratio have a positive effect on the probability of a currency crisis. Columns 1 and 4 in the two tables also show that the growth in the total private credit (household and firm credit combined) significantly increases the likelihood of having a currency crisis as the literature suggests.

Now, we turn our attention to the variables of interest: household and firm credit growth. We find a statistically significant positive effect of firm credit growth on currency crisis with both definitions of currency crisis. Similarly, household credit growth has a positive and statistically significant effect on currency crises using both crisis definitions and both the random effects and the population-averaged robust estimations. Unlike the results on banking crises, we find no evidence that the rate of savings influences these results. In terms of marginal effects, an increase of household credit growth from $1 \%$ to $2 \%$ of GDP leads to a 1.6 percentage points increase in the probability of having a currency crisis. The marginal effects of firm credit show a similar 
pattern with lower magnitudes. We find that an increase of firm credit growth from $1 \%$ to $2 \%$ of GDP leads to a $0.5 \%$ increase in the probability of having a currency crisis.

Overall, our estimation results show that household credit growth and firm credit growth have positive, distinct, and statistically significant effects on the likelihood of banking and currency crises. ${ }^{13}$ In terms of economic importance, the effect of credit growth on the likelihood of a banking crisis is stronger than the effect on a currency crisis. Furthermore, the effect of credit growth on banking crises depends on an economy's propensity to save. Household credit growth is a particularly important predictor of banking crises in countries with a traditionally low savings rate.

\section{Conclusion}

The literature has identified credit expansions as an important predictor of banking and currency crises in emerging markets. We confirm this finding and extend the literature by decomposing the total credit growth into household credit growth and firm credit growth. Our results show that the two types of credit have distinct and positive effects on the likelihood of financial crises, especially on banking crises.

Distinguishing between household and firm credit growth is important because in theory the two types of credit can affect the likelihood of financial crises in different ways as we discuss in section 2. Even if the channels of the effects are the same, empirical tests can show whether the strength of the effects differs. Furthermore,

\footnotetext{
${ }^{13}$ We also estimate the impact of household and firm credit growth on twin crises which are defined as the simultaneous occurrence of banking and currency crises. Our results suggest that household and firm credit growth have a positive and significant effect on twin crises, household credit growth being more dangerous in countries that have higher propensity to consume. In that regard, our results for twin crisis are in line with the results from the banking crisis estimation.
} 
household and firm credit expansions do not necessarily occur simultaneously. Looking at total credit growth does not reveal which component of credit is driving the growth.

Household credit is becoming increasingly important in the portfolios of commercial banks and is likely to increase in importance even further due to financial innovations. Also, household credit is growing rapidly in countries where only firms had access to credit until recently. Yet, the literature has not paid much attention to the macroeconomic implications of household credit. Our paper provides some preliminary evidence on the effect of household credit growth on banking and currency crises. However, distinguishing between household and firm credit in empirical and theoretical studies will become even more important as financial liberalizations take hold and financial systems around the world continue to develop. 


\section{REFERENCES}

Allen, Franklin and Douglas Gale. (2000). "Bubbles and Crises." The Economic Journal $110,236-255$.

Antzoulatos, A. Angelos. (1996). "Capital Flows and Current Account Deficits in the 1990s: Why did Latin American and East Asian Countries Respond Differently?" Federal Reserve Bank of New York, Research Paper No. 9610.

Bacchetta, Philippe and Stefan Gerlach. (1997). "Consumption and Credit Constraints: International Evidence.” Journal of Monetary Economics Vol. 40(2), 207-238 (October)

Bank for International Settlements. (2005). " $75^{\text {th }}$ Annual Report.” http://www.bis.org/publ/arpdf/ar2005e.pdf

Bayoumi, Tamim. (1993). "Financial Deregulation and Consumption in the United Kingdom.” The Review of Economics and Statistics, 75 (3), 536-539 (August).

Bernanke, Ben, Mark Gertler and Simon Gilchrist. (1999). "The Financial Accelerator in a Quantitative Business Cycle Framework.” In: Taylor, J., Woodford, M. (Eds.), Handbook of Macroeconomics. North-Holland.

Borio, Claudio and Philip Lowe. (2002). “Asset Prices, Financial and Monetary Stability: Exploring the Nexus.” BIS Working Papers, No: 114.

Calvo, Guillermo. (1983). "Staggered Prices in a Utility-maximizing Framework." Journal of Monetary Economics 12, 383-398.

Calvo, Guillermo. (1986). “Temporary Stabilization: Predetermined Exchange Rates.” Journal of Political Economy, Vol. 94, No. 6. 
Calvo, Guillermo, Leonardo Leiderman and Carmen Reinhart. (1996). "Inflows of Capital to Developing Countries in the 1990s." Journal of Economic Perspectives, 123-139.

Caprio, Gerard and Daniela Klingebiel. (2003). "Episodes of Systematic and Borderline Financial Crises." World Bank Mimeo.

Copelman, Martina. (1996). "The Role of Credit in Post-stabilization Consumption Booms." Board of Governors of the Federal Reserve System International Finance Discussion Papers No. 569

Corsetti, Giancarlo, Paolo Pesenti and Nouriel Roubini. (1999a). "Paper Tigers? A Model of the Asian Crisis." European Economic Review 43, 1211-1236.

Corsetti, Giancarlo, Paolo Pesenti and Nouriel Roubini. (1999b). "What Caused the Asian Currency and Financial Crises." Japan and the World Economy 11, 305373.

Demirgüç-Kunt, Asli and Enrica Detragiache. (1997). "The Determinants of Banking Crises in Developing and Developed Countries." IMF Staff Papers, 45, 81-109.

Duenwald, Christoph., Nikolay Gueorguiev and Andrea Schaechter. (2005). "Too Much of a Good Thing? Credit Booms in Transition Economies: The Case of Bulgaria, Romania, and Ukraine.” IMF Working Paper 05/128.

Frankel, Jeffrey and Andrew K. Rose. (1996). "Currency Crashes in Emerging Markets: An Empirical Treatment.” Journal of International Economics 41, 351-366.

Hilbers, Paul, Inci Otker-Robe, Ceyla Pazarbasioglu and Gudrun Johnsen. (2005). “Assessing and Managing Rapid Credit Growth and the Role of Supervisory and Prudential Policies." IMF Working Paper 05/151. 
Hong, Kiseok and Aaron Tornell. (2005). "Recovery from a Currency Crisis: Some Stylized Facts.” Journal of Development Economics 76, 71-96.

Jappelli, Tullio and Marco Pagano. (1994). "Saving, Growth and Liquidity Constraints." Quarterly Journal of Economics 109, 83-109.

Kaminsky, Graciela and Carmen Reinhart. (1999). "The Twin Crises: The Causes of Banking and Balance of Payments Problems." The American Economic Review 89 (3), 473-500 (June).

Kaminsky, Graciela and Sergio Schmukler. (2003). "Short-run Pain, Long-run Gain: The Effects of Financial Liberalization.” NBER Working Paper \#9787.

Kaminsky, Graciela, Saul Lizondo and Carmen Reinhart. (1998). "Leading Indicators of Currency Crisis.” IMF Staff Papers, Vol. 45, No: 1, International Monetary Fund, March 1998.

King, Robert and Ross Levine. (1993a). "Finance and Growth: Schumpeter Might be Right." Quarterly Journal of Economics 108 (3), 717-737 (August).

King, Robert and Ross Levine. (1993b). "Finance, Entrepreneurship, and Growth: Theory and Evidence.” Journal of Monetary Economics 32 (3), 513-542 (December).

Krugman, Paul. (1998). "What happened to Asia?" http://web.mit.edu/krugman/www/DISINTER.html

Levine, Ross. (1997). "Financial Development and Economic Growth: Views and Agenda.” Journal of Economic Literature 35 (2), 688-726.

Levine, Ross, Norman Loayza and Thomas Beck. (2000). "Financial Intermediation and Growth: Causality and Causes.” Journal of Monetary Economics 46 (1), 31-77. 
Ludvigson, Sidney. (1999). "Consumption and Credit: A Model of Time-Varying Liquidity Constraints.” Review of Economics and Statistics, 80(2), pp 251-262.

McKinnon, Ronald and Huw Pill. (1996). "Credible Liberalization and International Capital Flows: The Overborrowing Syndrome.” In T. Ito and A. Krueger, eds., Financial Deregulation and Integration in East Asia, Chicago: Chicago University Press.

McKinnon, Ronald and Huw Pill. (1997). "Credible Economic Liberalization and Overborrowing." American Economic Association Papers and Proceedings, 189193.

McKinnon, Ronald and Huw Pill. (1998). "International Overborrowing: A Decomposition of Credit and Currency Risks" World Development 26 (7), 12671282.

Miles, David. (1992). "Housing Markets, Consumption and Financial Liberalization in the Major Economies.” European Economic Review, 36, 1093-1127.

Muellbauer, John and Anthony Murphy. (1990). "The UK Current Account Deficit." Economic Policy, 347-95 (October).

International Monetary Fund, 2004. World Economic Outlook, April 2004, http://www.imf.org/external/pubs/ft/weo/2004/01/pdf/chapter4.pdf.

Rajan, Raghuram and Liugi Zingales. (1998). "Financial Dependence and Growth." The American Economic Review, Vol. 88, No. 3, 556-586.

Rodrik, Dani and Andrés Velasco. (1999). “Short-term Capital Flows.” NBER Working Paper 7364. 
Scheider, Martin and Aaron Tornell. (2004). "Balance Sheet Effects, Bailout Guarantees and Financial Crises." Review of Economic Studies, 883-913.

Wooldridge, J., 2002. Econometric Analysis of Cross Section and Panel Data, The MIT Press, 2001.

Zeger, L. Scott, Kung-Yee Liang, K. and Paul S. Albert. (1988). "Models for Longitudinal Data: A Generalized Estimating Equation Approach.” Biometrics 44, 1049-1060. 
Table 1: Household and Firm Credit Variable Description

\begin{tabular}{|c|c|c|c|}
\hline Country & Period & $\begin{array}{l}\text { Variable used for } \\
\text { Household Credit }\end{array}$ & $\begin{array}{l}\text { Variable used for } \\
\text { Firm Credit }\end{array}$ \\
\hline Argentina & 1991-1999 & $\begin{array}{l}\text { Family \& Individual } \\
\text { Loans }\end{array}$ & $\begin{array}{c}\text { Primary, Industry } \\
\text { and Services Sector } \\
\text { Loans }\end{array}$ \\
\hline Brazil & $1995-2004$ & $\begin{array}{c}\text { Housing \& } \\
\text { Individual Loans }\end{array}$ & $\begin{array}{c}\text { Industry, Rural and } \\
\text { Commerce Sector } \\
\text { Loans }\end{array}$ \\
\hline India & $1972-1996$ & Personal Loans & $\begin{array}{c}\text { Agriculture, } \\
\text { Industry, Transport } \\
\text { and Trade }\end{array}$ \\
\hline Indonesia & $1990-2003$ & Credit to Household & $\begin{array}{l}\text { Credit to Private } \\
\text { Enterprises }\end{array}$ \\
\hline Korea & 1994-2004 & Credit to Household & $\begin{array}{l}\text { Credit to Private } \\
\text { Enterprises }\end{array}$ \\
\hline Malaysia & 1996-2004 & Credit to Individuals & $\begin{array}{c}\text { Agriculture, Mining, } \\
\text { Manufacturing, } \\
\text { Trade and Services } \\
\text { Credit }\end{array}$ \\
\hline Mexico & 1994-2004 & $\begin{array}{l}\text { Credit to Housing } \\
\text { and Consumption }\end{array}$ & $\begin{array}{l}\text { Credit to Primary, } \\
\text { Industry \& Services }\end{array}$ \\
\hline Pakistan & 1983-2002 & Personal Loans & $\begin{array}{c}\text { Agriculture, } \\
\text { Industry, Transport } \\
\text { and Trade }\end{array}$ \\
\hline Russia & 1996-2004 & Household Credit & Corporate Credit \\
\hline South Africa & 1991-2004 & Household Credit & $\begin{array}{l}\text { Credit to Private } \\
\text { Enterprises }\end{array}$ \\
\hline Thailand & $1965-2004$ & $\begin{array}{c}\text { Personal } \\
\text { Consumption } \\
\text { Credit(Includes } \\
\text { Housing) }\end{array}$ & $\begin{array}{c}\text { Agriculture, Mining, } \\
\text { Manufacturing, } \\
\text { Trade and Services } \\
\text { Credit }\end{array}$ \\
\hline Turkey & $1986-2004$ & $\begin{array}{l}\text { Private Credit to } \\
\text { Households }\end{array}$ & $\begin{array}{c}\text { Private Credit to } \\
\text { Firms }\end{array}$ \\
\hline Uruguay & 1983-2001 & $\begin{array}{c}\text { Credit to } \\
\text { Households }\end{array}$ & $\begin{array}{c}\text { Agriculture, } \\
\text { Industry, Commerce } \\
\text { and Service Credit }\end{array}$ \\
\hline
\end{tabular}


Table 2:

Levels of Household and Firm Credit as percent of GDP

\begin{tabular}{ccccc}
\hline Country & $\begin{array}{c}\text { Household } \\
\text { Credit/GDP } \\
\text { Mean }\end{array}$ & $\begin{array}{c}\text { Firm } \\
\text { Credit/GDP } \\
\text { Mean }\end{array}$ & $\begin{array}{c}\text { Household } \\
\text { Credit/GDP } \\
\text { Growth } \\
\text { Mean }\end{array}$ & $\begin{array}{c}\text { Firm Credit/GDP } \\
\text { Growth } \\
\text { Mean }\end{array}$ \\
\hline Argentina & 5.06 & 8.26 & 0.55 & 0.34 \\
Brazil & 9.01 & 14.4 & -0.18 & -0.30 \\
India & 0.83 & 14.21 & 0.05 & 0.22 \\
Indonesia & 10.13 & 20.34 & -0.39 & -1.36 \\
Korea & 47.55 & 59.08 & 1.44 & -0.35 \\
Malaysia & 17.59 & 32.06 & 0.63 & -0.47 \\
Mexico & 17.52 & 30.73 & 1.03 & -0.23 \\
Pakistan & 1.91 & 12.96 & 0.006 & -0.009 \\
Russia & 0.90 & 11.04 & 0.23 & 1.70 \\
South Africa & 32.81 & 65.23 & 0.16 & 1.08 \\
Thailand & 5.92 & 37.08 & -0.30 & 0.44 \\
Turkey & 1.95 & 11.37 & 0.25 & -0.26 \\
Uruguay & 2.48 & 20.37 & 0.21 & -0.45 \\
\hline
\end{tabular}


Table 3: Descriptive Statistics

\begin{tabular}{|c|c|c|c|c|c|c|c|}
\hline Variable & $\begin{array}{l}\text { Household } \\
\text { credit } \\
\text { growth }\end{array}$ & $\begin{array}{l}\text { Firm credit } \\
\text { growth }\end{array}$ & $\begin{array}{l}\text { GDP } \\
\text { growth }\end{array}$ & $\begin{array}{c}\text { Current } \\
\text { account } \\
\text { balance to } \\
\text { GDP }\end{array}$ & $\begin{array}{l}\text { M2 to } \\
\text { reserves }\end{array}$ & $\begin{array}{c}\text { Bank } \\
\text { reserves } \\
\text { to assets }\end{array}$ & $\begin{array}{c}\text { Total } \\
\text { Debt to } \\
\text { GDP }\end{array}$ \\
\hline Mean & 0.25 & 0.03 & 4.32 & -0.60 & 6.35 & 9.13 & 7.31 \\
\hline Maximum & 7.08 & 10.31 & 13.28 & 18.03 & 31.12 & 34.13 & 35.40 \\
\hline Minimum & -4.19 & -13.01 & -13.12 & -8.53 & 1.31 & 1.56 & 0.78 \\
\hline Standard deviation & 1.36 & 2.97 & 4.47 & 4.50 & 4.82 & 6.57 & 6.10 \\
\hline $\begin{array}{l}\text { Correlations } \\
\text { Household credit } \\
\text { growth }\end{array}$ & 1.00 & & & & & & \\
\hline Firm credit growth & 0.33 & 1.00 & & & & & \\
\hline GDP growth & 0.10 & -0.02 & 1.00 & & & & \\
\hline $\begin{array}{l}\text { Current account } \\
\text { balance }\end{array}$ & -0.11 & -0.32 & -0.24 & 1.00 & & & \\
\hline M2 to reserves & -0.04 & 0.14 & 0.06 & -0.25 & 1.00 & & \\
\hline $\begin{array}{l}\text { Bank reserves to } \\
\text { assets }\end{array}$ & -0.01 & -0.06 & -0.10 & 0.02 & -0.04 & 1.00 & \\
\hline Total Debt to GDP & 0.07 & -0.24 & -0.17 & 0.25 & -0.30 & -0.16 & 1.00 \\
\hline
\end{tabular}


Table 4: Dates of Banking Crises

\begin{tabular}{ll}
\hline Country & Banking Crises \\
\hline Argentina & 1995 \\
Brazil & 1997 \\
Indonesia & 1997 \\
Korea & 1997 \\
Malaysia & 1997 \\
Mexico & 1995 \\
Russia & 1998 \\
Thailand & 1983,1997 \\
Turkey & 1994,2000 \\
\hline Total & 11 \\
\hline
\end{tabular}

Table 5: Dates of Currency Crises

\begin{tabular}{lll}
\hline Country & $\begin{array}{l}\text { Currency Crises defined by } \\
\text { depreciation and reserve losses }\end{array}$ & $\begin{array}{l}\text { Currency crises defined } \\
\text { by depreciation }\end{array}$ \\
\hline Argentina & 1991,1995 & 1991 \\
Brazil & 1999 & 1999 \\
Indonesia & 1997 & 1997 \\
Korea & 1997 & 1997 \\
Malaysia & 1997 & 1997 \\
Mexico & 1995 & 1995 \\
Russia & 1998 & 1998 \\
South Africa & 1996 & 1996,2001 \\
Thailand & 1997 & 1997 \\
Turkey & 1994,2001 & $1991,1994,2001$ \\
\hline Total & 12 & 13 \\
\hline
\end{tabular}


Table 6: Saving Rates

\begin{tabular}{cccc}
\hline Saving/GDP & $1976-1990$ & $1990-2004$ & $\mathbf{1 9 7 6 - 2 0 0 4}$ \\
\hline Argentina & 20.94 & 16.42 & 18.76 \\
Brazil & 18.88 & 18.58 & 18.74 \\
India & 12.05 & 13.89 & 12.93 \\
Indonesia & 26.52 & 24.54 & $\mathbf{2 5 . 4 4}$ \\
Korea & 29.96 & 34.71 & $\mathbf{3 2 . 1 6}$ \\
Malaysia & 25.86 & 34.77 & $\mathbf{3 0 . 0 0}$ \\
Mexico & 20.85 & 19.20 & 19.96 \\
Pakistan & 16.06 & 14.03 & 15.09 \\
Russia & - & 27.84 & $\mathbf{2 7 . 8 4}$ \\
South Africa & 24.78 & 16.08 & 20.58 \\
Thailand & 24.94 & 32.48 & $\mathbf{2 8 . 5 8}$ \\
Turkey & 16.47 & 20.76 & 18.54 \\
Uruguay & 13.61 & 13.31 & 13.46 \\
\hline
\end{tabular}


Table 7

Population-Averaged Robust and Random Effects Estimation

Credit growth and banking crisis: logit panel regression

\begin{tabular}{|c|c|c|c|c|c|c|}
\hline & (1) & (2) & (3) & (4) & (5) & (6) \\
\hline $\begin{array}{l}\text { Independent } \\
\text { Variables }\end{array}$ & $\begin{array}{l}\text { Pa Robust } \\
\text { Estimation }\end{array}$ & $\begin{array}{l}\text { Pa Robust } \\
\text { Estimation }\end{array}$ & $\begin{array}{l}\text { Pa Robust } \\
\text { Estimation }\end{array}$ & $\begin{array}{l}\text { Random } \\
\text { Effects }\end{array}$ & $\begin{array}{l}\text { Random } \\
\text { Effects }\end{array}$ & $\begin{array}{l}\text { Random } \\
\text { Effects }\end{array}$ \\
\hline $\begin{array}{l}\text { Total Credit } \\
\text { Growth }\end{array}$ & $\begin{array}{c}0.333 \\
(0.115)^{* * *}\end{array}$ & & & $\begin{array}{c}0.335 \\
(0.111)^{* * *}\end{array}$ & & \\
\hline $\begin{array}{l}\text { Household Credit } \\
\text { Growth }\end{array}$ & & $\begin{array}{c}0.451 \\
(0.132)^{* * * *}\end{array}$ & $\begin{array}{c}1.853 \\
(0.410)^{* * * *}\end{array}$ & & $\begin{array}{c}0.445 \\
(0.207)^{* *}\end{array}$ & $\begin{array}{c}1.822 \\
(0.594)^{* * * *}\end{array}$ \\
\hline $\begin{array}{l}\text { Firm Credit } \\
\text { Growth }\end{array}$ & & $\begin{array}{c}0.276 \\
(0.158)^{*}\end{array}$ & $\begin{array}{c}-1.106 \\
(0.297)^{* * *}\end{array}$ & & $\begin{array}{c}0.283 \\
(0.136)^{* *}\end{array}$ & $\begin{array}{c}-1.081 \\
(0.419)^{* * *}\end{array}$ \\
\hline $\begin{array}{l}\text { Household Credit } \\
\text { Growth*High } \\
\text { Saving Countries }\end{array}$ & & & $\begin{array}{c}-1.292 \\
(0.367)^{* * *}\end{array}$ & & & $\begin{array}{c}-1.277 \\
(0.594)^{* *}\end{array}$ \\
\hline $\begin{array}{c}\text { Firm Credit } \\
\text { Growth*High } \\
\text { Saving Countries }\end{array}$ & & & $\begin{array}{c}1.705 \\
(0.471)^{* * *}\end{array}$ & & & $\begin{array}{c}1.688 \\
(0.548)^{* * *}\end{array}$ \\
\hline $\begin{array}{l}\text { Bank Reserves } \\
\text { over Total Assets }\end{array}$ & $\begin{array}{l}-0.020 \\
(0.039)\end{array}$ & $\begin{array}{l}-0.026 \\
(0.039)\end{array}$ & $\begin{array}{l}-0.043 \\
(0.044)\end{array}$ & $\begin{array}{l}-0.021 \\
(0.055)\end{array}$ & $\begin{array}{l}-0.027 \\
(0.055)\end{array}$ & $\begin{array}{l}-0.041 \\
(0.060)\end{array}$ \\
\hline $\begin{array}{l}\text { M2 over } \\
\text { International } \\
\text { Reserves }\end{array}$ & $\begin{array}{l}-0.020 \\
(0.080)\end{array}$ & $\begin{array}{l}-0.016 \\
(0.074)\end{array}$ & $\begin{array}{c}0.067 \\
(0.073)\end{array}$ & $\begin{array}{l}-0.017 \\
(0.082)\end{array}$ & $\begin{array}{l}-0.011 \\
(0.081)\end{array}$ & $\begin{array}{c}0.068 \\
(0.084)\end{array}$ \\
\hline GDP Growth & $\begin{array}{c}-0.147 \\
(0.049)^{* * *}\end{array}$ & $\begin{array}{c}-0.162 \\
(0.050)^{* * *}\end{array}$ & $\begin{array}{c}-0.186 \\
(0.057)^{* * *}\end{array}$ & $\begin{array}{c}-0.145 \\
(0.065)^{* *}\end{array}$ & $\begin{array}{c}-0.157 \\
(0.070)^{* *}\end{array}$ & $\begin{array}{c}-0.180 \\
(0.077)^{* *}\end{array}$ \\
\hline Constant & $\begin{array}{c}-2.311 \\
(0.859)^{* * *}\end{array}$ & $\begin{array}{c}-2.523 \\
(0.916)^{* * *}\end{array}$ & $\begin{array}{c}-3.834 \\
(1.248)^{* * *}\end{array}$ & $\begin{array}{c}-2.319 \\
(0.870)^{* * *}\end{array}$ & $\begin{array}{c}-2.534 \\
(0.825)^{* * *}\end{array}$ & $\begin{array}{c}-3.809 \\
(1.111)^{* * *}\end{array}$ \\
\hline Observations & 177 & 177 & 177 & 177 & 177 & 177 \\
\hline $\begin{array}{c}\text { Number of } \\
\text { countries }\end{array}$ & 13 & 13 & 13 & 13 & 13 & 13 \\
\hline
\end{tabular}

Standard errors are in parentheses. ${ }^{*}, * *$, and ${ }^{* * *}$ indicate rejection at the 10 percent, 5 percent and 1 percent significance level. 


\section{Table 8}

\section{Population-Averaged Robust and Random Effects Estimation}

Credit growth and currency crisis defined using reserves and depreciation:

logit panel regression

\begin{tabular}{|c|c|c|c|c|c|c|}
\hline & (1) & $(2)$ & (3) & (4) & $(5)$ & (6) \\
\hline & $\begin{array}{l}\text { Pa Robust } \\
\text { Estimation }\end{array}$ & $\begin{array}{l}\text { Pa Robust } \\
\text { Estimation }\end{array}$ & $\begin{array}{l}\text { Pa Robust } \\
\text { Estimation }\end{array}$ & $\begin{array}{l}\text { Random } \\
\text { Effects }\end{array}$ & $\begin{array}{l}\text { Random } \\
\text { Effects }\end{array}$ & $\begin{array}{l}\text { Random } \\
\text { Effects }\end{array}$ \\
\hline $\begin{array}{l}\text { Total Credit } \\
\text { Growth }\end{array}$ & $\begin{array}{c}0.402 \\
(0.142)^{* * *}\end{array}$ & & & $\begin{array}{c}0.494 \\
(0.183)^{* * *}\end{array}$ & & \\
\hline $\begin{array}{l}\text { Household Credit } \\
\text { Growth }\end{array}$ & & $\begin{array}{c}0.611 \\
(0.190)^{* * *}\end{array}$ & $\begin{array}{c}0.828 \\
(0.742)\end{array}$ & & $\begin{array}{c}0.655 \\
(0.317)^{* *}\end{array}$ & $\begin{array}{c}0.813 \\
(0.603)\end{array}$ \\
\hline $\begin{array}{l}\text { Firm Credit } \\
\text { Growth }\end{array}$ & & $\begin{array}{c}0.317 \\
(0.167)^{*}\end{array}$ & $\begin{array}{l}-0.080 \\
(0.613)\end{array}$ & & $\begin{array}{c}0.399 \\
(0.204)^{* *}\end{array}$ & $\begin{array}{c}0.020 \\
(0.368)\end{array}$ \\
\hline $\begin{array}{l}\text { Household Credit } \\
\text { Growth*High } \\
\text { Saving Countries }\end{array}$ & & & $\begin{array}{l}-0.184 \\
(0.768)\end{array}$ & & & $\begin{array}{l}-0.150 \\
(0.663)\end{array}$ \\
\hline $\begin{array}{l}\text { Firm Credit } \\
\text { Growth*High }\end{array}$ & & & $\begin{array}{c}0.518 \\
(0.626)\end{array}$ & & & $\begin{array}{c}0.547 \\
(0.438)\end{array}$ \\
\hline $\begin{array}{c}\text { Saving Countries } \\
\text { Total Debt over } \\
\text { GDP }\end{array}$ & $\begin{array}{c}0.105 \\
(0.037)^{* * *}\end{array}$ & $\begin{array}{c}0.102 \\
(0.036) * * *\end{array}$ & $\begin{array}{c}0.100 \\
(0.043)^{* *}\end{array}$ & $\begin{array}{c}0.120 \\
(0.073)^{*}\end{array}$ & $\begin{array}{c}0.116 \\
(0.070)^{*}\end{array}$ & $\begin{array}{c}0.112 \\
(0.075)\end{array}$ \\
\hline $\begin{array}{c}\text { Current Account } \\
\text { Balance }\end{array}$ & $\begin{array}{c}-0.314 \\
(0.087)^{* * *}\end{array}$ & $\begin{array}{c}-0.334 \\
(0.097)^{* * *}\end{array}$ & $\begin{array}{c}-0.335 \\
(0.104) * * *\end{array}$ & $\begin{array}{c}-0.374 \\
(0.176)^{* *}\end{array}$ & $\begin{array}{c}-0.374 \\
(0.172)^{* *}\end{array}$ & $\begin{array}{c}-0.368 \\
(0.164)^{* *}\end{array}$ \\
\hline GDP Growth & $\begin{array}{c}-0.377 \\
(0.121)^{* * *}\end{array}$ & $\begin{array}{c}-0.415 \\
(0.121)^{* * *}\end{array}$ & $\begin{array}{c}-0.441 \\
(0.122) * * *\end{array}$ & $\begin{array}{c}-0.396 \\
(0.120) * * *\end{array}$ & $\begin{array}{c}-0.419 \\
(0.129)^{* * *}\end{array}$ & $\begin{array}{c}-0.433 \\
(0.134)^{* * *}\end{array}$ \\
\hline $\begin{array}{c}\text { M2 over } \\
\text { International } \\
\text { Reserves }\end{array}$ & $\begin{array}{c}0.126 \\
(0.064)^{* *}\end{array}$ & $\begin{array}{c}0.134 \\
(0.066)^{* *}\end{array}$ & $\begin{array}{c}0.160 \\
(0.075)^{* *}\end{array}$ & $\begin{array}{c}0.167 \\
(0.183)^{*}\end{array}$ & $\begin{array}{c}0.163 \\
(0.088)^{*}\end{array}$ & $\begin{array}{c}0.181 \\
(0.088)^{* *}\end{array}$ \\
\hline Constant & $\begin{array}{c}-4.688 \\
(1.293)^{* * *}\end{array}$ & $\begin{array}{c}-4.736 \\
(1.308) * * *\end{array}$ & $\begin{array}{c}-4.940 \\
(1.222)^{* * *}\end{array}$ & $\begin{array}{c}-5.613 \\
(1.463)^{* * *}\end{array}$ & $\begin{array}{c}-5.453 \\
(1.460) * * *\end{array}$ & $\begin{array}{c}-5.584 \\
(1.478)^{* * *}\end{array}$ \\
\hline Observations & 168 & 168 & 168 & 168 & 168 & 168 \\
\hline $\begin{array}{l}\text { Number of } \\
\text { Countries }\end{array}$ & 13 & 13 & 13 & 13 & 13 & 13 \\
\hline
\end{tabular}

Standard errors are in parentheses. ${ }^{*}, * *$, and $* * *$ indicate rejection at the 10 percent, 5 percent and 1 percent significance level. 


\section{Table 9}

\section{Population-Averaged Robust and Random Effects Estimation}

Credit growth and currency crisis defined using depreciation:

logit panel regression

\begin{tabular}{|c|c|c|c|c|c|c|}
\hline & (1) & (2) & (3) & (4) & (5) & (6) \\
\hline & $\begin{array}{l}\text { Pa Robust } \\
\text { Estimation }\end{array}$ & $\begin{array}{l}\text { Pa Robust } \\
\text { Estimation }\end{array}$ & $\begin{array}{l}\text { Pa Robust } \\
\text { Estimation }\end{array}$ & $\begin{array}{l}\text { Random } \\
\text { Effects }\end{array}$ & $\begin{array}{l}\text { Random } \\
\text { Effects }\end{array}$ & $\begin{array}{l}\text { Random } \\
\text { Effects }\end{array}$ \\
\hline $\begin{array}{l}\text { Total Credit } \\
\text { Growth }\end{array}$ & $\begin{array}{c}0.349 \\
(0.125)^{* * *}\end{array}$ & & & $\begin{array}{c}0.458 \\
(0.160)^{* * *}\end{array}$ & & \\
\hline $\begin{array}{l}\text { Household Credit } \\
\text { Growth }\end{array}$ & & $\begin{array}{c}0.454 \\
(0.129)^{* * *}\end{array}$ & $\begin{array}{c}0.549 \\
(0.471)\end{array}$ & & $\begin{array}{c}0.531 \\
(0.317)^{*}\end{array}$ & $\begin{array}{c}0.591 \\
(0.521)\end{array}$ \\
\hline Firm Credit Growth & & $\begin{array}{c}0.303 \\
(0.160)^{*}\end{array}$ & $\begin{array}{c}0.025 \\
(0.452)\end{array}$ & & $\begin{array}{c}0.428 \\
(0.195)^{* *}\end{array}$ & $\begin{array}{c}0.145 \\
(0.309)\end{array}$ \\
\hline $\begin{array}{l}\text { Household Credit } \\
\text { Growth*High } \\
\text { Saving Countries }\end{array}$ & & & $\begin{array}{l}-0.058 \\
(0.528)\end{array}$ & & & $\begin{array}{l}-0.021 \\
(0.635)\end{array}$ \\
\hline $\begin{array}{l}\text { Firm Credit } \\
\text { Growth*High }\end{array}$ & & & $\begin{array}{c}0.378 \\
(0.441)\end{array}$ & & & $\begin{array}{c}0.491 \\
(0.408)\end{array}$ \\
\hline $\begin{array}{c}\text { Saving Countries } \\
\text { Total Debt over } \\
\text { GDP }\end{array}$ & $\begin{array}{c}0.091 \\
(0.026)^{* * *}\end{array}$ & $\begin{array}{c}0.089 \\
(0.026)^{* * *}\end{array}$ & $\begin{array}{c}0.083 \\
(0.033)^{* *}\end{array}$ & $\begin{array}{c}0.121 \\
(0.076)\end{array}$ & $\begin{array}{c}0.121 \\
(0.077)\end{array}$ & $\begin{array}{c}0.116 \\
(0.084)\end{array}$ \\
\hline $\begin{array}{l}\text { Current Account } \\
\text { Balance }\end{array}$ & $\begin{array}{c}-0.233 \\
(0.072)^{* * *}\end{array}$ & $\begin{array}{c}-0.238 \\
(0.074)^{* * *}\end{array}$ & $\begin{array}{c}-0.235 \\
(0.082)^{* * *}\end{array}$ & $\begin{array}{l}-0.304 \\
(0.162)^{*}\end{array}$ & $\begin{array}{l}-0.306 \\
(0.164)^{*}\end{array}$ & $\begin{array}{c}-0.311 \\
(0.163)^{*}\end{array}$ \\
\hline GDP Growth & $\begin{array}{c}-0.287 \\
(0.083)^{* * *}\end{array}$ & $\begin{array}{c}-0.303 \\
(0.081)^{* * *}\end{array}$ & $\begin{array}{c}-0.318 \\
(0.080)^{* * *}\end{array}$ & $\begin{array}{c}-0.320 \\
(0.107)^{* * *}\end{array}$ & $\begin{array}{c}-0.328 \\
(0.112)^{* * *}\end{array}$ & $\begin{array}{c}-0.341 \\
(0.118)^{* * *}\end{array}$ \\
\hline $\begin{array}{l}\text { M2 over } \\
\text { International } \\
\text { Reserves }\end{array}$ & $\begin{array}{c}0.107 \\
(0.040)^{* * *}\end{array}$ & $\begin{array}{c}0.111 \\
(0.039)^{* * *}\end{array}$ & $\begin{array}{c}0.132 \\
(0.047)^{* * *}\end{array}$ & $\begin{array}{c}0.152 \\
(0.087)^{*}\end{array}$ & $\begin{array}{c}0.153 \\
(0.088)^{*}\end{array}$ & $\begin{array}{c}0.168 \\
(0.091)^{*}\end{array}$ \\
\hline Constant & $\begin{array}{c}-4.171 \\
(1.053)^{* * *}\end{array}$ & $\begin{array}{c}-4.155 \\
(1.041)^{* * *}\end{array}$ & $\begin{array}{c}-4.260 \\
(0.993)^{* * *}\end{array}$ & $\begin{array}{c}-5.395 \\
(1.508)^{* * *}\end{array}$ & $\begin{array}{c}-5.448 \\
(1.519)^{* * *}\end{array}$ & $\begin{array}{c}-5.658 \\
(1.570)^{* * *}\end{array}$ \\
\hline Observations & 168 & 168 & 168 & 168 & 168 & 168 \\
\hline $\begin{array}{l}\text { Number of } \\
\text { Countries }\end{array}$ & 13 & 13 & 13 & 13 & 13 & 13 \\
\hline
\end{tabular}

Standard errors are in parenthesis. ${ }^{*}, * *$, and ${ }^{* * *}$ indicate rejection at the 10 percent, 5 percent and 1 percent significance level. 